\title{
Peningkatan Kemampuan Membaca Permulaan melalui Permainan Kartu Huruf Mata Pelajaran Bahasa Indonesia di Sekolah Dasar
}

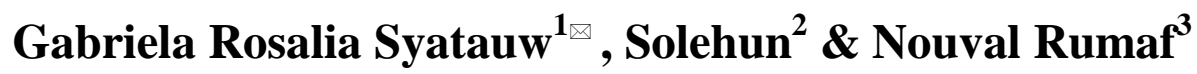

Program Studi PGSD, Universitas Pendidikan Muhammadiyah Sorong, Indonesia

$\bowtie$ E-mail: gabrielarosalia8@gmail.com

\begin{abstract}
Abstrak
Tujuan penelitian ini adalah untuk meningkatkan proses pelaksanaan pembelajaran membaca permulaan melalui permainan kartu huruf dapat meningkatkan hasil keterampilan membaca siswa. Subjek penelitian ini adalah siswa kelas IB SD Inpres 16 Kabupaten Sorong yang berjumlah 25 siswa. Jenis penelitian ini adalah PTK (Penelitian Tindakan Kelas). Teknik pengumpulan data menggunakan tes dan observasi. Instrument pengumpulan data adalah tes hasil belajar siswa dan lembar observasi. Teknik analisis data yang digunakan adalah analisis data deskriptif kuantitatif dan desskriptif kualitatif. Proses pembelajaran siklus I guru menerapkan permainan kartu huruf. Siklus II guru menerapkan permainan kartu huruf dan diskusi kelompok. Pada siklus III guru masih menggunakan permainan kartu huruf dan diskusi kelompok. Hasil siklus I keterampilan membaca siswa mengalami peningkatan dari hasil pratindakan nilai rata-rata 57 meningkat menjadi 60, dan siswa yang mencapai KKM sebanyak 76\%. Siklus II nilai rata-rata meningkat menjadi 64 dan siswa yang telah mencapai KKM sebanyak $92 \%$. Siklus III nilai rata-rata meningkat menjadi 71 dengan nilai ketuntasan siswa 96\%. Dari hasil penelitian menunjukkan bahwa permainan kartu huruf dapat meningkatkan keterampilan membaca siswa.
\end{abstract}

Kata Kunci: Kemampuan Membaca Permulaan; Permainan Kartu Huruf; Pembelajaran Bahasa Indonesia.

\begin{abstract}
The purpose of this research is to increase the reading learning process in the beginning through letter card game can increase the result of student reading skills. This Research subject is the students in the class IB Inpres 16 Elementary school of Sorong Regency totally 25 of them. Kind of this research is ACR (Action in the Class Research) or PTK (Penelitian Tindakan Kelas). The data accumulation technic is using test and observation. The data analysis technic used is descriptive quantitative data analysis and descriptive qualitative. Learning process cycle I teacher apply the letter card game. Cycle II teacher still teacher apply the letter card game and group discussion. Cycle III teacher still using the letter card game and group discussion. The result of cycle I the student reading skills have increase from pre-action the average score is 57 goes up to 60, and the student reached the KKM is 76\%. Cycle II average score goes up to 64 and students reached the KKM is $92 \%$. Cycle III the average score goes up to 71 with student competence score is $96 \%$. From the research result is showing that letter card game can increase the student reading skills.
\end{abstract}

Keywords: Reading Skill; Letter Card Game; Indonesia Language Learning. 


\section{PENDAHULUAN}

Membaca permulaan merupakan tahap awal anak dalam proses belajar membaca. Membaca permulaan sebagai keterampilan dasar membaca siswa dan alat bagi siswa untuk mengetahui makna dari isi mata pelajaran yang dipelajarinya di sekolah. Semakin cepat siswa dapat membaca makin besar peluang untuk memahami isi makna mata pelajaran di sekolah. Sebagai ketermpilan yang mendasari keterampilan berikutnya maka keterampilan membaca permulaan harus benar-benar diperhatikan oleh guru. Pembelajaran membaca di sekolah diajarkan melalui pelajaran bahasa indonesi. Pembelajaran membaca di kelas I dan II itu merupakan pembelajaran membaca tahap awal. (Rahayu, 2012).

Pembelajaran bahasa Indonesia memiliki kedudukan yang sangat penting. Bahasa Indonesia merupakan mata pelajaran yang wajib untuk semua jenjang pendidikan termaksud untuk siswa SD. Ada empat keterampilan berbahasa dalam kurikulum di sekolah, yakni keterampilan mendengar, membaca, berbicara dan menulis. Siswa SD diharapkan mampu untuk mengusai keempat komponen kebahasaan tersebut. (Muliyati, 2014).

Setiap pengajaran bahasa bertujuan agar para siswa mempunyai pemahaman terhadap keterampilan berbahasa.Terampil berbahasa berarti terampil menyimak, terampil berbicara, terampil membaca, dan terampil menulis.Terampil berbahasa sangat diperhatikan dan dikembangkan karena membaca dapat membuat seseorang bisa mendeskripsikan keadaan yang terjadi walaupun masih dalam bentuk teks namun, seakan-akan seseorang berada dalam keadaan dan suasana tersebut. Oleh karena itu, kemampuan membaca sangat dibutuhkan oleh siswa untuk dapat memahami berbagai informasi yang dibaca (Hamilatur Rizqiyah,
2015).

Pembelajaran membaca permulaan dapat memberikan pengalaman pada peserta didik yaitu dengan melibatkan langsung peserta didik pada proses pembelajaran seperti permainan bahasa dan juga pemakaian media yang dapat melibatkan siswa. Untuk itu guru perlu menyediakan pembelajaran yang menarik yang dapat menimbulkan daya tarik bagi siswa untuk giat secara aktif dan kreatif. Hal yang sama juga disampaikan oleh Arsyad (2014), bahwa pemakaian media pembelajaran dalam proses pembelajaran dapat membangkitkan keinginan dan minat yang baru serta membangkitkan motivasi dan rangsangan kegiatan belajar (Ari Musodah, 2014).

Kartu huruf merupakan media atau alat dalam mencapai suatu keberhasilan dalam suatu tujuan yang ditetapkan oleh seorang guru atau pendidik. Menurut Hamali (2014: 12), bahwa media pembelajaran adalah metode atau teknik yang digunakan untuk mengefektifkan komunikasi dan interaksi antara guru dan siswa dalam proses pendidikan dan pengajaran. Selanjutnya menurut Suyanto (2014) mengungkapkan bahwa, pada dasarnya pendidikan Anak Usia Dini lebih menekankan pada kegiatan bermain sambil belajar yang mengandung arti setiap kegiatan pembelajaran yang menyenangkan. Melalui bermain, banyak konsep dasar dari pengetahuan dapat diperoleh, seperti konsep dasar warna, ukuran, bentuk, dan arah yang merupakan dasar dari perkembangan bahasa(Ari Musodah, 2014).

Manfaat penelitian adalah berguna untuk mengetahui model pembelajaran yang bisa mempengaruhi peningkatan kemampuan membaca permulaan siswa dan siswa didorong untuk memperoleh pengetahuan melalui permainan kartu huruf.

$$
\text { Pembelajaran dikenal dengan }
$$


"pengajaran", “belajar-mengajar". Padanan kata pembelajaran kata pembelajaran dalam bahasa asing (Inggris) yaitu "instructional", yang di dalamnya mengandung makna interaksi antara peserta didik dengan lingkungan dan sumber belajar. Di dalam Undang-Undang Nomor 20 Tahun 2003 tentang Sistem Pendidikan Nasional dijelaskan bahwah pembelajaran adalah proses interaksi peserta didik dengan pendidik dan sumber belajar pada suatu lingkungan belajar. pembelajaran adalah interaksi antara peserta didik dan lingkungannya dimana peserta didik membuat kemajuan dalam pencapaian pengetahuan yang spesifik dan bertujuan, keterampilan dan sikap (Alis Qomariyatun, 2013). Selanjutnya, pembelajaran adalah suatu usaha yang disengaja, bertujuan dan terkendali agar orang lain belajar atau terjadi perubahan yang relatif menetap pada diri orang lain. Usaha ini dapat dilakukan oleh seseorang atau suatu tim yang memiliki kemampuan dan kompetensi dalam merancang dan mengembangkan sumber belajar yang diperlukan (Rahayu, 2012).

Berdasarkan uraian para ahli diatas, maka dapatlah dimaknai bahwa pembelajaran merupakan aktivitas dan proses yang sistematis dan sistemik yang terdiri dari beberapa komponen yaitu: pendidik/pengajar, kurikulum, peserta didik, metode, strategi, sumber belajar, fasilitas dan administrasi. Masing-masing komponen tidak bersifat parsial (terpisah) atau berjalan sendiri-sendiri, tetapi berjalan secara teratur, saling bergantung, komplementer dan berkesinambungan sehingga diharapkan melaluinya peserta didik dapat melakukan aktivitas belajar secara baik dan tentunya diharapkan pula hasil belajarnya berupa pengetahuan, sikap dan keterampilan dapat tercapai pula.

Hasil belajar merupakan hasil yang diperoleh siswa setelah proses pembelajaran, umumnya hasil belajar merupakan nilai baik berupa mentah ataupun sudah diakumulasikan. Interaksi antara pendidik dengan peserta didik yang dilakukan secara sadar, terencana baik didalam maupun di luar ruangan untuk meningkatkan kemampuan peserta didik ditentukan oleh hasil belajar. Hasil belajar adalah suatu perubahan yang terjadi pada seseorang yang belajar, bukan saja perubahan mengenai pengetahuan tetapi juga perubahan untuk membentuk kecakapan, kebisaan sikap, pengertian, penguasaan, penghargaan dalam diri seseorang yang belajar (Toheri, 2009). Selanjutnya, Hasil belajar adalah kemampuan baru yang diperoleh siswa setelah mereka mengikuti kegiatan proses belajar-mengajar pada mata pelajaran tertentu, (Widayanti, 2013).

Berdasarkan pengertian di atas, maka dapat disimpulkan bahwa hasil belajar adalah proses perubahan kemampuan yang dimiliki oleh siswa setelah ia menerima pembelajaran atau pengalaman belajarnya. Dengan mengetahui hasil belajar siswa, guru dapat mengetahui perkembangan kemampuan yang dimiliki oleh siswa.

Bahasa adalah satu alat komunikasi, melalui bahasa manusia dapat saling berkomunikasi, saling berbagai pengalaman, saling belajar dari yang lain, dan meningkatkan kemampuan intelektual. Oleh karena itu belajar bahasa pada hakikatnya adalah belajar komunikasi. Pembelajaran dalam berkomunikasi, baik lisan maupun tertulis, ini sesuai pendapat Resmini, 2014:49 yang mengemukakan bahwa pembelajaran Bahasa Indonesia dapat diartikan sebagai sebuah pembelajaran untuk meningkatkan kemampuan siswa dalam komunikasi dengan bahasa baik lisan maupun tulis.

Membaca permulaan merupakan tahapan proses belajar membaca bagi siswa sekolah 
dasar kelas awal. Siswa belajar untuk memperoleh kemampuan dan menguasai teknik-teknik membaca dan menangkap isi bacaan dengan baik. Membaca pada tingkatan ini merupakan kegiatan belajar mengenal bahasa tulis.melalui tulisan itulah siswa dituntut dapat menyuarakan lambanglambang bunyi bahasa tersebut, untuk memperoleh kemampuan membaca diperlukan tiga syarat, yaitu kemampuan membunyikan (a) lambang-lambang tulis, (b) penguasaan kosakata untuk memberi arti, dan (c) memasukkan makna dalam kemahiran bahasa. Membaca permulaan merupakan suatu proses keterampilan dan kognitif. Proses keterampilan menunjuk pada pengenalan dan penguasaan lambanglambang, sedangkan proses kognitif menunjuk pada penggunaan lambang-lamang kalimat. Perilaku anak kadang kala berperan sehingga mengakibatkan anak kesulitan dalam mengenal huruf dipengaruhi oleh memori jangka pendek, (Windrawati. 2020).

Kartu huruf adalah kartu kecil yang berisi gambar, teks, atau tanda simbol yang mengingatkan atau tanda simbol yang mengingatkan atau mengarahkan siswa kepada suatu yang berhubungan dengan gambar.Kartu huruf biasanya berukuran 8-12 $\mathrm{cm}$, atau dapat disesuaikan dengan besar kecilnya kelas yang dihadapi (Fajriati, 2017). Selanjutnya, Kartu Huruf merupakan media pembelajaran yang berupa kartu bergambar berukuran 25-30 cm. Gambar-gambar pada Kartu Huruf merupakan serangkaian pesan yang disajikan dengan adanya keterangan pada setiap gambar (Rifa Imami, 2011).

Dari beberapa pendapat di atas, dapat disimpulkan bahwa Kartu Huruf adalah kartu belajar yang efektif mempunyai dua sisi dengan salah satu sisi berisi gambar, teks, atau tanda simbol dan sisi lainnya berupa definisi, keterangan gambar, jawaban, atau uraian yang membantu mengingatkan atau mengarahkan siswa kepada sesuatu yang berhubungan dengan gambar yang ada pada kartu. Kartu angka biasanya berukuran 8-12 $\mathrm{cm}, 25-30 \mathrm{~cm}$, atau dapat disesuaikan dengan besar kecilnya kelas yang dihadapi.Kartu angka atau kartu bergambar merupakan media grafis yang praktis dan aplikatif.

Penggunaan kartu huruf pada pembelajaran bahasa Indonesia aspek membaca dapat meningkatkan keterampilan dan motifasi belajar siswa kelas awal hal ini terbukti dengan beberapa penelitian yang pernah dilakukan sebelumnya yaitu penelitian yang dilakukan oleh Prehatin (2010:66) dari hasil penelitian menyebutkan dengan kartu huruf yang menggunakan fariasi warna dan dalam pelaksanaannya melibatkan siswa dalam pengoperasian kartu dapat meningkatkan hasil belajar membaca siswa, nilai rerata mengalami peningkatan dari kondisi awal 60 meningkat 79,8 kemudian presentasi ketuntasan juga mengalami peningkatan dari kondisi awal $26 \%$ meningkat menjadi $92 \%$ (Sahrudin, 2005).

\section{METODE PENELITIAN}

Dalam penelitian ini adalah jika pembelajaran dilaksanakan melalui permainan kartu huruf maka dapat meningkatkan kemampuan membaca siswa kelas IB SD Inpres 16 Kabupaten Sorong.

Data dan sumber yang digunakan merupakan keterangan tentang sesuatu objek penelitian. Definisi data sebenarnya punya kemiripan dengan definisi informasi, hanya informasi lebih ditonjolkan dari segi servis, sedangkan data lebih ditonjolkan aspek materi. Data utama dalam penelitian ini berupa data kuantitatif dan data kualitatif. Data-data tersebut diambil dari; Skor hasil tes siswa dalam mengerjakan soal-soal yang diberikan, meliputi skor hasil tes awal dan hasil tes pada setiap akhir tindakan.

Hasil lembar observasi aktivitas 
pembelajaran. Yang dimaksud dengan sumber data adalah subjek dari mana data dapat diperoleh. Jadi sumber data ini menunjukkan asal informasi. Data ini harus diperoleh dari sumber data yang tepat. Jika sumber data tidak tepat maka mengakibatkan data yang terkumpul tidak relevan dengan masalah yang diselidiki. Sumber data dari penelitian ini adalah siswa kelas I SD Inpres 16 Kabupaten Sorong.

\section{HASIL DAN PEMBAHASAN}

Nilai ketuntasan membaca permulaan siswa pada saat pratindakan adalah $64 \%$ atau sebanyak 16 siswa. Sedangkan siswa yang dinyatakan belum tuntas ada $36 \%$ atau 9 siswa. Adapun KKM Bahasa Indonesia pada aspek membaca adalah 65. Nilai rata-rata keterampilan membaca siswa pada saat pratindakan adalah 57,76. Lebih jelas dapat dilihat pada tabel 1 .

Tabel 1. Distribusi frekuensi nilai keterampilan membaca permulaan pra tindakan.

\begin{tabular}{|c|c|c|c|c|c|c|}
\hline $\begin{array}{l}\mathbf{N} \\
\text { o. }\end{array}$ & $\begin{array}{l}\text { Inter } \\
\text { val } \\
\text { nilai }\end{array}$ & $\begin{array}{l}\text { kateg } \\
\text { ori }\end{array}$ & $\begin{array}{l}\text { Freku } \\
\text { ensi } \\
\text { siswa }\end{array}$ & $\begin{array}{l}\text { Presen } \\
\text { tasi } \\
(\%)\end{array}$ & $\begin{array}{l}\text { Rat } \\
\text { a- } \\
\text { rat } \\
\text { a }\end{array}$ & $\begin{array}{l}\text { Present } \\
\text { asi } \\
\text { ketunta } \\
\text { san } \\
(\%)\end{array}$ \\
\hline 1 & $85-100$ & $\begin{array}{l}\text { Sangat } \\
\text { baik }\end{array}$ & 5 & 20 & \multirow{6}{*}{$\begin{array}{l}57, \\
76\end{array}$} & \multirow{6}{*}{64} \\
\hline 2 & $70-84$ & Baik & 1 & 4 & & \\
\hline 3 & $55-69$ & cukup & 10 & 40 & & \\
\hline 4 & $40-54$ & kurang & 4 & 16 & & \\
\hline 5 & $<40$ & $\begin{array}{l}\text { Sangat } \\
\text { kurang }\end{array}$ & 5 & 20 & & \\
\hline & & umlah & & 100 & & \\
\hline
\end{tabular}

\section{Deskripsi Hasil Siklus I}

Data jumlah siswa yang memiliki keterampilan membaca permulaan dengan kategori sangat baik ada 5 siswa, kategori baik ada 1 siswa, kategori cukup ada 13 siswa, dan kategori kurang ada 2 siswa. Hasil ini menunjukkan bahwa data pra tindakan yang dilakukan masih berada pada kategori yang masih tergolong kategori cukup Jadi, jumlah siswa yang telah mencapai KKM yaitu ada 19 siswa atau sekitar $76 \%$. Nilai rata-rata kelas 60,24.

Tabel 2. Distribusi frekuensi nilai keterampilan membaca permulaan siklus I

\begin{tabular}{|c|c|c|c|c|c|c|}
\hline No & $\begin{array}{l}\text { Inter } \\
\text { val } \\
\text { nilai }\end{array}$ & $\begin{array}{l}\text { kateg } \\
\text { ori }\end{array}$ & $\begin{array}{l}\text { Frekue } \\
\text { nsi } \\
\text { siswa }\end{array}$ & $\begin{array}{l}\text { Present } \\
\text { asi } \\
(\%)\end{array}$ & $\begin{array}{l}\text { Rat } \\
\text { a- } \\
\text { rata }\end{array}$ & $\begin{array}{l}\text { Presen } \\
\text { tasi } \\
\text { ketunt } \\
\text { asan } \\
(\%) \\
\end{array}$ \\
\hline 1 & $\begin{array}{l}85- \\
100\end{array}$ & $\begin{array}{l}\text { Sangat } \\
\text { baik }\end{array}$ & 5 & 20 & $\begin{array}{l}60 \\
24\end{array}$ & 76 \\
\hline 2 & $70-84$ & Baik & 1 & 4 & & \\
\hline 3 & $55-69$ & cukup & 13 & 52 & & \\
\hline 4 & $40-54$ & kurang & 2 & 8 & & \\
\hline 5 & $<40$ & $\begin{array}{l}\text { Sang } \\
\text { at } \\
\text { kuran } \\
\text { g }\end{array}$ & 4 & 16 & & \\
\hline & & Jumlah & & 100 & & \\
\hline
\end{tabular}

Hasil refleksi pada siklus I memberikan kesimpulan bahwa pembelajaran yang berlangsung masih ada beberapa kekurangan yang mengakibatkan belum tercapainya keberhasilan peneliti. Namun sudah ada peningkatan pada hasil tes keterampilan membaca siswa. Peningkatan keterampilan membaca permulaan siswa dapat dilihat dari hasil nilai rata-rata kondisi awal yaitu 57,76, meningkat pada siklus I menjadi 60,24. Kenaikan juga terjadi pada nilai siswa yang sudah mencapai KKM yaitu meningkat dari $64 \%$ menjadi $76 \%$.

\section{Deskripsi Hasil Siklus II}

Pembelajaran setelah melewati siklus I selanjutnya diteruskan pada Siklus II untuk mencari peningkatan kemampuan yang terjadi pada siklus berikutnnya. Hal tersebut dilakukan untuk mendapatkan hasil tuntas secara klasikal atau secara individu.

hasil tes keterampilan membaca permulaan siswa pada siklus II. Ada 5 siswa masuk dalam kategori sangat baik, 1 siswa dalam kategori baik, 17 siswa dalam kategori cukup, dan 2 siswa dalam kategori kurang. Tabel di atas menunjukkan ada 23 siswa atau 92\% sudah mencapai KKM. Rata-rata nilai siswa mencapai 64,92 . Lebih jelasnya dapat dilihat pada tabel 3 . 
Tabel 3. distribusi frekuensi nilai keterampilan membaca permulaan siklus II

\begin{tabular}{|c|c|c|c|c|c|c|}
\hline No & $\begin{array}{l}\text { Inter } \\
\text { val } \\
\text { nilai }\end{array}$ & $\begin{array}{l}\text { kateg } \\
\text { ori }\end{array}$ & $\begin{array}{l}\text { Freku } \\
\text { ensi } \\
\text { siswa }\end{array}$ & $\begin{array}{l}\text { Presen } \\
\text { tasi } \\
(\%) \\
\end{array}$ & $\begin{array}{l}\text { Rata- } \\
\text { rata }\end{array}$ & $(\%)$ \\
\hline 1 & $\begin{array}{l}85- \\
100\end{array}$ & $\begin{array}{l}\text { Sangat } \\
\text { baik }\end{array}$ & 5 & 20 & $\begin{array}{l}64, \\
92\end{array}$ & 92 \\
\hline 2 & $70-84$ & Baik & 1 & 4 & & \\
\hline 3 & 55-69 & cukup & 17 & 68 & & \\
\hline 4 & $40-54$ & kurang & 2 & 8 & & \\
\hline 5 & $<40$ & $\begin{array}{l}\text { Sangat } \\
\text { kurang }\end{array}$ & - & & & \\
\hline
\end{tabular}

\section{Deskripsi Hasil Siklus III}

Hasil refleksi pada siklus III memberikan kesimpulan bahwa pembelajaran sudah berlangsung baik. Secara umum tidak ditemukan kendala yang berarti, karena pelaksanaan siklus III ini merupakan perbaikan dari kekurangan pada siklus sebelumnya. Hal ini ditunjukkan dengan adanya peningkatan yang cukup signifikan pada keterampilan membaca siswa. Peningkatan keterampilan membaca permulaan siswa dapat dilihat dari hasil nilai rata-rata siklus II yaitu 60 meningkat pada siklus III menjadi 71. Kenaikan juga terjadi pada nilai siswa yang sudah mencapai KKM yaitu meningkat dari $92 \%$ menjadi $96 \%$. Lebih jelas dapat dilihat pada tabel 4 .

Tabel 4. Distribusi frekuensi nilai keterampilan membaca permulaan siklus III

\begin{tabular}{|c|c|c|c|c|c|c|}
\hline No & $\begin{array}{l}\text { Inte } \\
\text { rval } \\
\text { nilai }\end{array}$ & $\begin{array}{l}\text { kateg } \\
\text { ori }\end{array}$ & $\begin{array}{l}\text { Freku } \\
\text { ensi } \\
\text { siswa }\end{array}$ & $\begin{array}{l}\text { Pres } \\
\text { enta } \\
\text { si } \\
(\%)\end{array}$ & $\begin{array}{l}\text { Rata- } \\
\text { rata }\end{array}$ & $\begin{array}{l}\text { Presen } \\
\text { tasi } \\
\text { ketunt } \\
\text { asan } \\
(\%)\end{array}$ \\
\hline 1 & $\begin{array}{l}85- \\
100\end{array}$ & $\begin{array}{l}\text { Sangat } \\
\text { baik }\end{array}$ & 5 & 20 & 71,64 & 96 \\
\hline 2 & $\begin{array}{l}70- \\
84\end{array}$ & Baik & 5 & 20 & & \\
\hline 3 & $\begin{array}{l}55- \\
69\end{array}$ & cukup & 14 & 56 & & \\
\hline 4 & $\begin{array}{l}40- \\
54\end{array}$ & kurang & 1 & 4 & & \\
\hline \multirow[t]{2}{*}{5} & $<40$ & $\begin{array}{l}\text { Sangat } \\
\text { kurang }\end{array}$ & - & & & \\
\hline & & Jumlah & & 100 & & \\
\hline
\end{tabular}

Data menunjukkan bahwa hasil siklus 3 mencapai pada presentasi tuntas secara klasikal.

\section{KESIMPULAN}

Penerapan

pendekatan

belajar

menggunakan permainan kartu huruf pada siswa kelas I SD Inpres 16 Kabupaten Sorong semester ganjil pada tahun pelajaran 2019/2020 dengan adanya perbaikan yang terus dilakukan pada setiap siklusnya dapat meningkatkan aktivitas dan hasil belajar siswa. Hal ini terlihat dari:

Presentasi siswa yang tuntas belajar meningkat setiap siklusnya, yaitu pada siklus I sebesar $72 \%$, pada siklus II mengalami peningkatan menajadi $76 \%$ dan pada akhir akhir siklus ini telah mencapai indikator keberhasilan penelitian.

Rata-rata nilai siswa senantiasa mengalami peningkatan setiap siklusnya, yaitu 65,32 pada siklus I, naik menjadi 73,12 pada siklus II dan pada siklus III menjadi 77,44. Hal ini menunjukkan bahwa pembelajaran melalui permainan kartu huruf dapat meningkatkan hasil belajar siswa kelas I SD Inpres 16 Kabupaten Sorong.

Beberapa masalah yang ditemui dalam pelaksanaan antara lain pengelolaan kelas selama pembelajaran, namun masalah itu dapat diatasi dengan adanya perbaikan pada setiap siklus yaitu memberikan motivasi kepada siswa, pemberian penghargaan, dan penyajian masalah sehari-hari yang menarik pada lembar kerja siswa.

\section{DAFTAR RUJUKAN}

Ahmadi, F. (2010). Meningkatkan Minat Membaca Siswa Sekolah Dasar Dengan Metode Gleen Doman Berbasis Multimedia, 27.

Alis Qomariyatun. (2013). Peningkatan Kemampuan Membaca Dan Berhitung Melalui Permainan Kartu Huruf, Gambar Dan Angka Pada Pembelajaran Tematik (Bahasa Indonesia Dan Matematika) Pada 
Siswa Kelas I Sekolah Dasar Negeri 01 Gedungan Kecamatan Karanganyar Tahun Pelajaran 2012/2013.

Ari Musodah. (2014). Peningkatan Kemampuan Membaca Permulaan Melalui Media Kartu Kata Bergambar Pada Anak Kelompok B2 Ra Ma'arif $\mathrm{Nu}$ Karang Tengah Kertanegara Purbalingga.

Hamilatur Rizqiyah. (2015). Peningkatan Kualitas Pembelajaran Bahasa Indonesia Melalui Strategi Know Want Learned Dengan Media Puzzle Pada Kelas IV SDN Purwoyoso 06 Semarang.

H. Darmadi. (2017). Pengembangan Model Dan Metode Pembelajaran Dalam Dinamika Belajar Siswa. Yogyakarta : Cv. Budi Utama. Perpustakaan Nasional.

Ibadullah Malawi \& Dr. Ani Kadarwati. (2017). Jawa Timur : Cv. Ae Media Grafika.

Lefudin. (2014). Belajar Dan Pembelajaran. Yogyakarta : Cv Budi Utama. Perpustakaan Nasional.

Rahayu, S. (2012). Upaya Meningkatkan Kemampuan Membaca Melalui Permainan Kartu Huruf Pada Siswa
Kelas I SDN 1 Bulurejo Kecamatan Gadingrejo Kabupaten Pringsewu.

Rusman. (2017). Belajar Dan Pembelajaran

Berorientasi Standar Proses

Pendidikan. Jakarta : Kencana.

Perpustakaan Nasional.

Sahrudin, B. (2005). Peningkatan Kemampuan Membaca Permulaan Siswa Kelas 1 SDN Ginunggung Melalui Media Kartu Huruf Kec . Galang, 4(10), 62-77.

Trianto. (2011). Desain Pengembangan Pembelajaran Tematik Bagi Anak Usia Dini Tk/Ra \& Anak Kelas Sd/Mi . Jakarta : Kencana. Perpustakaan Nasional : Katalog Dalam Terbitan (Kdt)

Trisniwati. (2014). Peningkatan Kemampuan Mengenal Huruf Melalui Metode Permainan Kartu Huruf Pada Kelompok B1 Tk Aba Ketanggungan Wirobrajan Yogyakarta.

Windrawati, W., Solehun, S., \& Gafur, H. (2020). Analisis Faktor Penghambat Belajar Membaca Permulaan pada Siswa Kelas I SD Inpres 141 Matalamagi Kota Sorong. Jurnal Papeda (Publikasi Pendidikan Dasar), 2 (1), 10-16. 